日臨外会誌 $61(9), 2377-2380,2000$

症例

悪性狭窄と鑑別が困難であった術後遅発性大腸狭窄の 1 例

東京慈恵会医科大学外科（主任：青木照明教授）
河 原 秀次郎
山 崎 一

63歳, 男性. 平成 3 年11月脾維曲部近傍の横行結腸癌のため他院で左半結腸切除術が 施行され, さらに平成10年12月 S 状結腸早期癌のため同院で $\mathrm{S}$ 状結腸部分切除術が施行 された. 平成11年 5 月下旬より下腹部痛が出現し，6月10日イレウスの診断で同院に緊 急入院した。精查により $\mathrm{S}$ 状結腸術後吻合部狭窄によるイレウスと判明し, 術後吻合部 再発の可能性を考慮し当科に紹介された，大腸内視鏡検查では，吻合部と思われる部位 に全周性狭䆣がみられたが, 生検所見を含めて明瞭な腫場性成分は検出されず, バルー ンを用いた内視鏡的拡張術を試みた。その後, 精查により術後虚血性変化による良性狭 窄と判明し, 吻合部は左精巣動脈より栄養されていた，術後良性狭窄は 3 力月以内に生 じることが多く本症例のように術後 6 力月経過して生じることは極めて稀である. 術後 の虚血性変化に伴い吻合部周囲の血管新生によって血行支配に変化が生じたことが原因 と考えられた。

索引用語： delayed stricture, ischemic change, endoscopic dilatation

\section{緒 言}

大腸癌術後の吻合狭窄は, 癌の吻合部再発を常に念 頭におかなければならないが，良性狭窄は術後 3 力月 以内に生じることが多く 3 力月以降に狭窄が生じるこ とは比較的稀とされている ${ }^{1221}$. 著者らは 2 回の大腸癌 手術後 6 力月経過して吻合部狭窄が生じ，イレウスを 呈した症例を経験した，結局，良性狭窄であったため 内視鏡的拉張術によって軽快したが，今後予想される 高齢化社会において異時性多発癌が増加し，大腸を複 数回手術する機会も増加するものと考えられ，その合 併症として本症例は重要と考えられたので報告する。

$$
\text { 症例 }
$$

患者：63歳, 男性.

主訴：腹部膨満, 下腹部痛.

家族歴：特記すべきことなし。

既往歴: 平成 3 年11月脾彎曲部近傍の横行結腸癌の ため他院にて左半結腸切除術施行. 平成10年12月S状結 腸早期癌のため同院にて S 状結腸部分切除術を施行.

2000 年 3 月 8 日受付 2000 年 6 月 9 日採用

〈所属施設住所〉

テ105-8461 東京都港区西新橋 4-25- 8
現病率：平成11年 5 月下旬より下腹部痛が生じ， 6 月10日イレウスの診断で近医（手術が行われた病院） に緊急入院した。精査によりS 状結腸術後の吻合部に 狭窄が指摘され, 術後吻合部再発の可能性を考え当科 に精查加療目的で紹介された。

注腸所見：S 状結腸術後の吻合部と考えられる部位 に狭害が認められ，压迫によっても伸展性が不良であ った（図 1 )。

大腸内視鏡検查所見 $: \mathrm{S}$ 状結腸術後の吻合部と考え られる部位に全周性の狭窄が認められたが, 腫瘍を疑 わせる所見は観察されなかった(図 2). 生検でも腫瘍 成分は認められなかったため, バルーンによる拡張術 を施行した. 拡張時軽度の疼痛を伴ったが比較的容易 に狭害部が搪張された（図3）。

血管造影所見：下腸間膜動脈は手術によってすでに 処理されていたため左精巣動脈を造影したが,この動 脈によって狭窄部を含む腸管が支配されているものと 考えられた（図4).

治療経過：入院時腹部 X線検查で haustra を有する 大腸ガス像と鏡面形成像が認められイレウスを呈して いたため，禁飲食として中心静脈栄養を開始した，血 液生化学検査では特に異常所見はみられず, 腫瘍マー 


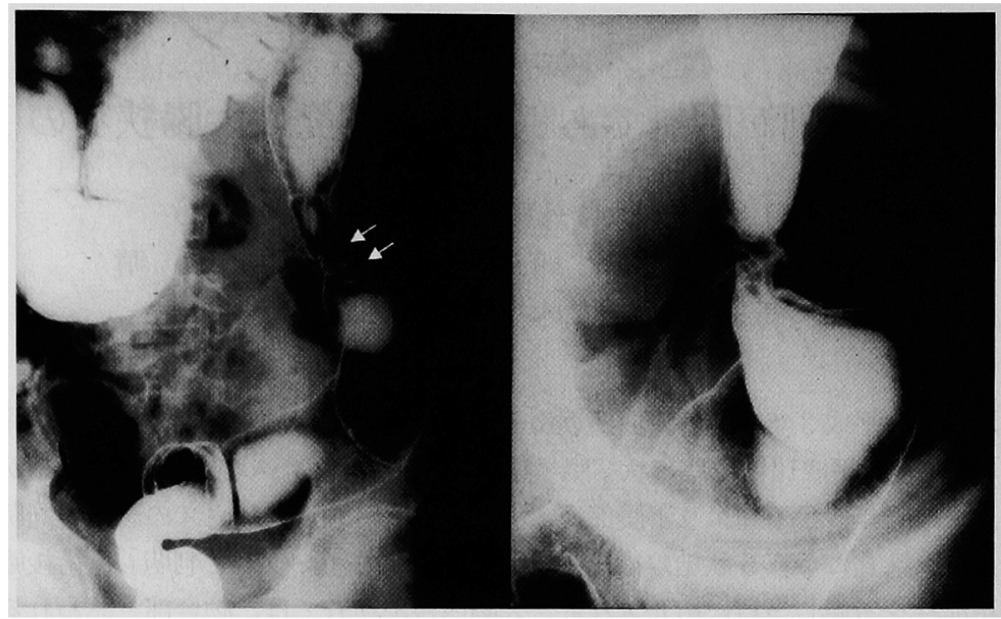

図 1 注腸検査所見 (左；注腸像，右；圧迫像）：S 状結腸術後吻合部と考えられ る部位に狭窄が認められ（矢印，压迫によっても伸展性が不良であった。

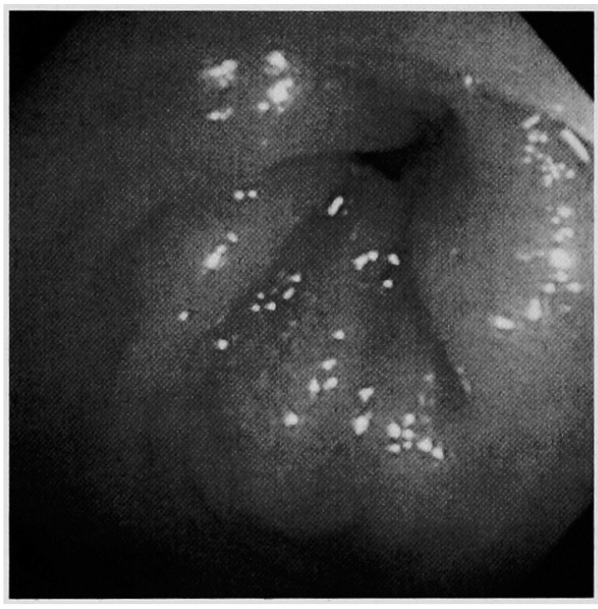

図 2 大腸内視鏡検査所見（検查）：術後吻合部 と考えられる部位に全周性の狭窄が認められ たが, 明瞭な腫瘍性成分は観察されなかった。

カーも正常範囲であった(表 1 ). その後計 3 回の内視 鏡的拡張術を施行したが，その都度行った生検組織診 断で悪性所見が全くみられなかったため，いままでの 経過加ら考え吻合部狭窄は癌の再発ではなく良性狭窄 と判断した。

内視鏡的拡張術終了後外来通院をされているが，退 院後半年上経過した現在狭窄症状は全くみられていな w.

\section{考察}

大腸手術の腸管吻合後の主な合併症は縫合不全と吻 合部狭窄である，結腸結腸吻合での合併症の頻度は，

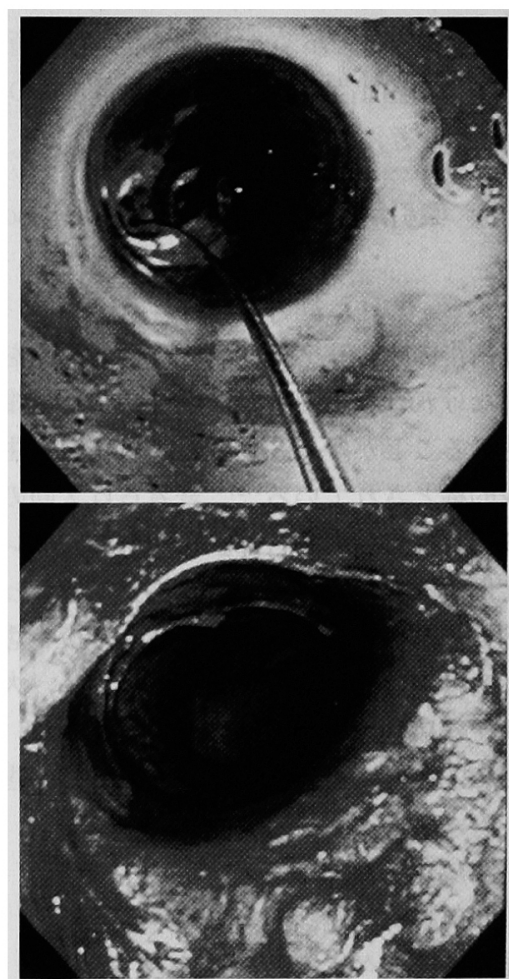

図 3 大腸内視鏡検查所見（治療：上： バルーンを用いて拡張術中の所見, 下：拡張術後の所見)：バルーンを用 いた拡張術を施行したが，比较的容易 に狭窄部が拡張しだ。

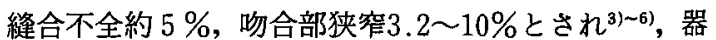
械吻合を用いた場合の吻合部狭窄の頻度は3.7〜20\% 


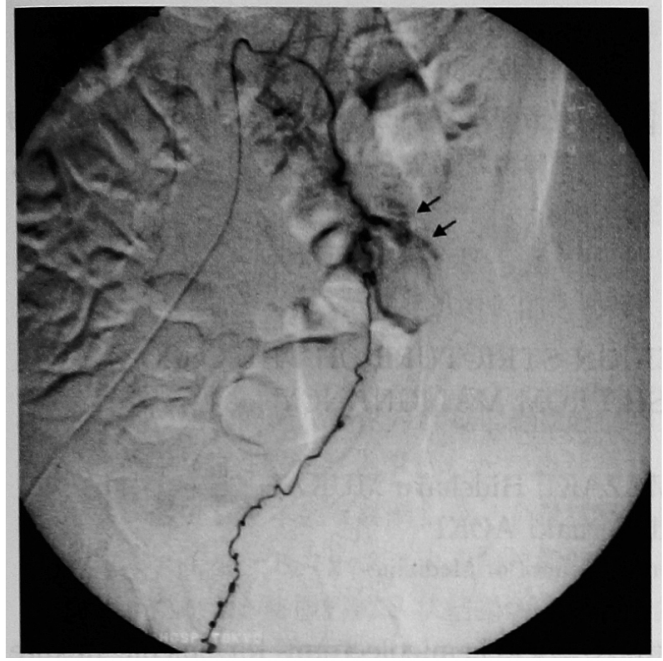

図 4 血管造影挨査所見：左精栄動脈によって狭窄 部を含む腸管が栄養されていた。

とする報告がみられる57)．吻合部狭窄の原因について は過度の縫合による吻合口の狭窄，吻合口の浮腫およ び周囲の血腫，二層縫合の不揃い，痣着による二次性 狭窄などが挙げられる ${ }^{8}$. 一般的に吻合部はときとと もに大きくなるが，循環障害や縫合不全の場合は非可 逆性の狭窄をきたすとされている9．また好発部位と しては吻合部位が左結腸部，下行結腸部になった場合 に多く認められたという報告がみられる10).

本症例では，他院で左半結腸切除術とその後 S 状結 腸部分切除術の計 2 回の手術が施行されているが，手 術によって下腸間膜動脈がその根部ですでに処理され ているため，吻合部の血行は中結腸動脈からの腸管辺 缘動脈之直腸側からの腸管辺緑動脈が考えられ，吻合 部の血流は良好とは言い難い，実際に血管造影による 検索では吻合部を栄蔶していたのは左精巣動脈であっ た.

大腸疾患術後良性狭窄は術後 3 力月以内に生じるこ とが多く，3力月以降に狭窄が生じることは比較的稀 とされているが(12), 本症例の吻合部狭窄が遷延した理 由としては, 術後の虚血性変化に伴い吻合部周囲に血 管新生が生し，左精巣動脈と吻合部栄養血管が交通し たためと考えられる．また左精巣動脈と吻合部栄養血 管が交通していたことが，吻合部自体の重篤な虚血性 変化が回避され，当科に扔ける内視鏡的治療の効果が 得られた要因の 1 つとも考えられる。ところで腸管の 栄養血管と精巣動脈などの他藏器栄養血管が術後に交 通することは極めて稀であり，これまでに報告例をみ
表 1 入院時検査所見

\begin{tabular}{|c|c|c|c|c|}
\hline 血䍇一般 & \multicolumn{4}{|c|}{ 血液生化学 } \\
\hline WBC & $10,000 / \mathrm{mm}^{3}$ & AST & 27 & $\mathrm{IU} / \mathrm{L}$ \\
\hline $\mathrm{RBC}$ & $4.19 \times 105 / \mathrm{mm}^{3}$ & ALT & 53 & $\mathrm{IU} / \mathrm{L}$ \\
\hline $\mathrm{Hb}$ & $12.4 \mathrm{~g} / \mathrm{dl}$ & $\mathrm{ChE}$ & 365 & $\mathrm{IU} / \mathrm{L}$ \\
\hline $\mathrm{Ht}$ & $37.3 \%$ & $\mathrm{~T}-\mathrm{Bil}$ & 0.3 & $\mathrm{mg} / \mathrm{dl}$ \\
\hline \multirow[t]{2}{*}{ Plt } & $350,000 / \mathrm{mm}^{3}$ & ALP & 340 & $\mathrm{IU} / \mathrm{dl}$ \\
\hline & & $\gamma-\mathrm{GT}$ & 34 & $\mathrm{IU} / \mathrm{L}$ \\
\hline 腫鴻マーカー & & TP & 7.9 & $\mathrm{~g} / \mathrm{dl}$ \\
\hline CEA & $4.5 \mathrm{ng} / \mathrm{dl}$ & Alb & 4.3 & $\mathrm{~g} / \mathrm{dl}$ \\
\hline \multirow[t]{6}{*}{ CA19-9 } & $4.0 \mathrm{ng} / \mathrm{dl}$ & UN & 16 & $\mathrm{mg} / \mathrm{dl}$ \\
\hline & & $\mathrm{Cr}$ & 0.7 & $\mathrm{mg} / \mathrm{dl}$ \\
\hline & & $\mathrm{Na}$ & 136 & $\mathrm{mEq} / \mathrm{L}$ \\
\hline & & $\mathrm{K}$ & 4.5 & $\mathrm{mEq} / \mathrm{L}$ \\
\hline & & $\mathrm{Cl}$ & 99 & $\mathrm{mEq} / \mathrm{L}$ \\
\hline & & CRP & 0.3 & $\mathrm{mg} / \mathrm{dl}$ \\
\hline
\end{tabular}

ない.

今後高齢化社会がすすむにつれ，異時性多発癌が増 加し，複数回の大腸手術を受けなければならない症例 が増加するものと考えられ，吻合部の虚血性変化によ る狭窄症例に遭遇する機会が増加することが予想され る。術後吻合部狭窄が良性であった場合には，まず balloonなどを用いた内視鏡的拡張術を試み，観血的 治療はできるだけ避けるべきであると思われた。

結語

大腸癌術後遅発性吻合部狭㠰を経験した。吻合部栄 養血管が左精巣動脈と術後交通したことが重篤な虚血 性変化を呈するに至らず，内視鏡的治療の効果が上げ られた要因の 1 つと考えられた。

$$
\text { 文献 }
$$

1）夏越祥次, 島津久明：腹部手術後の消化管狭窄一 特に吻合部狭䂟について一.外科診療 $6: 749-$ 755,1992

2）高橋寿久，永田 博，佐野 淳他：上部消化管器 械吻合術々後吻合部狭窄に対する内視鏡的切開. Gastroenterol Endosc 34 : 2003-2008, 1992

3）中山隆市：消化管手術と器械吻合, 歴史と最近の 動向. 臨外 35：1225-1237，1980

4）浜野恭一：低位前方切除術. 日消外会誌 18 ： 1917-1920, 1985

5）唐牛 忍，森田隆幸，藤田正弘他：直腸癌低位前 方切除術における器械吻合. 手術 $38: 807-813$, 1984

6) Sharefkin J, Joffe $N$, Silen $W$, et al : Anas tomotic dehiscence after resection of the rec- 
tum. Am J Surg $135:$ 519-523, 1987

7) 中山隆市：器械吻合総論。日消外会誌 $18: 1905$

$-1908,1985$

8）西 満正，太田博俊：縫合不全吻合部通過障害.

外科治療 $52 ： 656-658,1985$
9）前谷俊三，西川俊邦，小野寺久他：結腸切除術. 外科䛦療 $30: 644-649,1988$

10）白井芳則，小野正人，新井竜夫他：結腸癌術後吻 合部障害の検討. 日臨外医会誌 $57: 2629-2633$ ， 1996

\title{
A CASE OF POSTOPERATIVE DELAYED BENIGN STRICTURE OF THE COLON WITH DIFFICULTY IN DISTIGUISH FROM MALIGNANCY
}

\author{
Hidejiro KAWAHARA, Kazuya YAMAZAKI, Hideharu MUKAI, \\ Mikiya KASHIWAGI and Teruaki AOKI \\ Department of Surgery, Jikei University School of Medicine
}

A 63-year-old man, who has undergone two operations, a left hemicolectomy for splenic flexure tumor in November 1991 and partial sigmoidectomy for early cancer in December 1998, was admitted emergently to the same hospital because of lower abdominal pain lasting for ten days on June 101999 . He was diagnosed as having ileus due to anastomosis stenosis after the partial sigmoidectomy. He was referred to the hospital because his stricture might have malignancy. Colonoscopy revealed complete stenosis at a portion of the colon which seemed like operative anastomosis. However, no clear tumor lesion was observed. After a biopsy, we tried to dilate the stenosis by endoscopic procedure with a balloon. After all it was conceivable that postoperative ischemic change would make the stricture. And the strictural lesion was given blood supply by only the left gonadal artery. Postoperative benign stricture usually occurs within three months after the operation. So the reported case is thought to be rare because the stricture was revealed over six months after the operation. Angiogenesis of perianastomosis may be responsible for this delayed stricture. 